\title{
Characteristics and chemical reactivity of biogenic volatile organic compounds from dominant forest species in the Jing-Jin-Ji area, China
}

Ying Lin ${ }^{1}$, Xiaoxiu Lun ${ }^{1 *}$, Wei Tang ${ }^{2}$, Zhongzhi Zhang ${ }^{2}$, Xiaoxi Jing ${ }^{1}$, Chong Fan ${ }^{1}$ and Qiang Wang ${ }^{1 *}$

\begin{abstract}
Background: Biogenic volatile organic compounds (BVOCs) play an essential role in tropospheric atmospheric chemical reactions. There are few studies conducted on BVOCs emission of dominant forest species in the Jing-Jin$\mathrm{Ji}$ area of China. Based on the field survey, forest resources data and the measured standard emission factors, the Guenther model developed in 1993 (G93) was applied in this paper to estimate the emission of BVOCs from several dominant forest species (Platycladus orientalis, Quercus variabilis, Betula platyphylla, Populus tomentosa, Pinus tabuliformis, Robinia pseudoacacia, Ulmus pumila, Salix babylonica and Larix gmelinii) in the Jing-Jin-Ji area in 2017. Then the spatiotemporal emission characteristics and atmospheric chemical reactivity of these species were extensively evaluated.
\end{abstract}

Results: The results showed that the total annual BVOCs emission was estimated to be $70.8 \mathrm{Gg} C \cdot y e a r^{-1}$, consisting $40.5 \%$ (28.7 Gg C.year ${ }^{-1}$ ) of isoprene, $36.0 \%$ (25.5 Gg C.year ${ }^{-1}$ ) of monoterpenes and $23.4 \%$ (16.6 Gg C.year ${ }^{-1}$ ) of other VOCs. The emissions from Platycladus orientalis, Quercus variabilis, Populus tomentosa and Pinus tabulaeformis contributed $56.1 \%, 41.2 \%, 36.0 \%$ and $31.1 \%$, respectively. The total BVOCs emission from the Jing-Jin-Ji area accounted for $61.9 \%$ and $1.8 \%$ in summer and winter, respectively. Up to $28.8 \%$ of emission was detected from Chengde followed by Beijing with $24.9 \%$, that mainly distributed in the Taihang Mountains and the Yanshan Mountains. Additionally, the Robinia pseudoacacia, Populus tomentosa, Quercus variabilis, and Pinus tabulaeformis contributed mainly to BVOCs reaction activity.

Conclusions: The BVOCs emission peaked in summer (June, July, and August) and bottomed out in winter (December, January, and February). Chengde contributed the most, followed by Beijing. Platycladus orientalis, Quercus variabilis, Populus tomentosa, Pinus tabulaeformis and Robinia pseudoacacia represent the primary contributors to BVOCs emission and atmospheric reactivity, hence the planting of these species should be reduced.

Keywords: Biogenic volatile organic compounds (BVOCs), Isoprene, Monoterpenes, Jing-Jin-Ji area, Spatiotemporal characteristics, Chemical reactivity

\footnotetext{
* Correspondence: lunxiaoxiu@bjfu.edu.cn; qiangwang@bjfu.edu.cn

${ }^{1}$ College of Environmental Science and Engineering, Beijing Forestry

University, 100083 Beijing, China

Full list of author information is available at the end of the article
}

\section{Springer Open}

(c) The Author(s). 2021 Open Access This article is licensed under a Creative Commons Attribution 4.0 International License, which permits use, sharing, adaptation, distribution and reproduction in any medium or format, as long as you give appropriate credit to the original author(s) and the source, provide a link to the Creative Commons licence, and indicate if changes were made. The images or other third party material in this article are included in the article's Creative Commons licence, unless indicated otherwise in a credit line to the material. If material is not included in the article's Creative Commons licence and your intended use is not permitted by statutory regulation or exceeds the permitted use, you will need to obtain permission directly from the copyright holder. To view a copy of this licence, visit http://creativecommons.org/licenses/by/4.0/. 


\section{Background}

Biogenic volatile organic compounds (BVOCs) are low boiling point compounds commonly synthesized by secondary metabolic pathways in plants. Many vascular plants can discharge BVOCs into the atmosphere (Loreto and Schnitzler 2010). Forest is one of the primary sources that emit BVOCs, which occupies about $70 \%$ of the total BVOCs amounts from vegetation. It was estimated that the annual emission of BVOCs in the world was about $10^{6} \mathrm{Gg} C \cdot$ year $^{-1}$ (Guenther et al. 2012), accounting for more than $90 \%$ of the total non-methane volatile organic compounds (NMVOCs) emission on the ground and far exceeding the anthropogenic compounds (Guenther et al. 1995). Isoprene (the simplest 5-carbon isoprenoid, $\mathrm{C}_{5} \mathrm{H}_{8}$, 2-methyl 1,3-butadiene) represents the highest emission component (Atkinson and Arey 2003) with an approximately $50 \%$ of the total annual global emissions of BVOCs in around 412-601 Tg C.year ${ }^{-1}$ (Guenther et al. 2012). Monoterpenes are the 10-carbon isoprenoids that account for about $15 \%$ (32-157 Tg C.year ${ }^{-1}$ ) of global BVOCs emission (Guenther et al. 2012). Both isoprene and monoterpenes are synthesized by the MEP pathway (Loreto and Schnitzler 2010). BVOCs are usually formed constitutively or after stress induction. Those components can improve plant tolerance towards abiotic stressors such as high temperature, oxidative stress and biotic stressors (e.g. competing plants and microorganisms) (Loreto and Schnitzler 2010; Filella et al. 2013).

BVOCs play an essential role in tropospheric atmospheric chemical reactions (Sartelet et al. 2012; Kulmala et al. 2013). BVOCs are the main precursors to form tropospheric ozone and atmospheric aerosols, promoting the formation of secondary pollutants such as peroxyacetyl nitrate (PANs), secondary organic aerosols (SOA), particulate matter (PM), aldehydes and ketones (Claeys et al. 2004; Laothawornkitkul et al. 2009). In particular, the formation of ozone occurs when the isoprene is dissociated and react with $\mathrm{NO}_{x}$ (Fehsenfeld et al. 1992) while the formation medium of secondary organic aerosols (Claeys et al. 2004) is contributed by monoterpenes and sesquiterpenes via cloud condensation nuclei, hence affecting the local or global climate.

The Jing-Jin-Ji area locating on the North China Plain represents the core of north China and the most developed city cluster in China. With the rapid development of the economy and the acceleration of urbanization, the issue of air pollution requires immediate attention. The Jing-Jin-Ji area has been plagued by severe photochemical pollution and haze for many years (Tang et al. 2009; Han et al. 2013). It is known that the accumulation of particulate matter, primarily fine particulate matter $\mathrm{PM}_{2.5}$ is the main factor that causes the haze (Li et al. 2013; Zhai et al. 2016; Hsu et al. 2017; Zhao et al. 2013) showed that the hourly average concentration of $\mathrm{PM}_{2.5}$ in Beijing reached $318 \mu \mathrm{g} \cdot \mathrm{m}^{-3}$ on hazy days. Several cities in Hebei province suffered more severe air pollution (Wang et al. 2012; Li et al. 2016a) used the $\mathrm{PM}_{2.5}$ monitoring data of 161 cities to analyze the $\mathrm{PM}_{2.5}$ pollution in mainland China. The results showed that the Jing-JinJi and its surrounding areas were heavily polluted and ranked at one of China's current four smoggy regions. Zhao et al. (2020) demonstrated that the average annual $\mathrm{PM}_{2.5}$ concentration in the Jing-Jin-Ji area decreased by $8.66 \mu \mathrm{g} \cdot \mathrm{m}^{-3}$ from 2014 to 2018 , indicating the population that exposed to high $\mathrm{PM}_{2.5}$ concentration was decreasing. However, the average annual $\mathrm{PM}_{2.5}$ concentration value was still far from the national standard limit $\left(35 \mu \mathrm{g} \cdot \mathrm{m}^{-3}\right)$. Also, the ozone is another important pollutant that plagues the urban ambient air quality after $\mathrm{PM}_{2.5}$ (Meng et al. 2017; Chen et al. 2013) reported that the ozone mixing ratio in the Jing-Jin-Ji area was very high, thus causing strong photochemical reactions from May to September. Wang et al. (2017) pointed out that the ozone concentration had exceeded the standard by $100-200 \%$ in the Jing-Jin-Ji area. During 2014-2018, the ozone concentration in the Jing-Jin-Ji area showed an upward trend with an average positive annual level of $4.90 \mu \mathrm{g} \cdot \mathrm{m}^{-3}$ as reported by Zhao et al. (2020). Some studies indicated that the contribution of BVOCs such as monoterpenes and sesquiterpenes to SOA formation was substantial (Steinbrecher et al. 2009; Aksoyoglu et al. 2011; Ghirardo et al. 2016) found that the contribution of BVOCs released by vegetation to SOA generation in Beijing was increased by two-fold within 20052010. Carlo et al. (2004) reported that the isoprene is highly reactive with hydroxyl radical $(\cdot \mathrm{OH})$ than most anthropogenic volatile organic compounds (AVOCs). Geng et al. (2011) suggested that BVOCs can contribute to the surface ozone concentrations. The above literatures show that the role of BVOCs in ozone formation cannot be ignored in the Jing-Jin-Ji area especially during summer (Xie et al. 2008; Ran et al. 2011), which would have led to severe impacts on human health, economic development, ecological environment, and climate change (Pierre et al. 2017). Considering the particular geographical location, diverse vegetation composition, and the enormous influence of BVOCs on ozone and secondary aerosols, it is crucial to clarify the BVOCs emission emitted from dominant forest species in the Jing-Jin-Ji area.

At present, the estimation of BVOCs emission from plants have been conducted through various studies using different methods, including models, land cover and meteorological data. Different results of the Jing-JinJi area were obtained from different models and input parameters at home and abroad (Klinger et al. 2002; Song et al. 2012; Li et al. 2016b). Most of the previous 
estimations were conducted by grouping the forest species into several plant functional types (PFT) and then using the global average emission rates and biomass density of each vegetation type. However, such estimation was unsatisfactory because the differences between plant species and regions were ignored (Xia and Xiao 2019). Besides, most of the studies employed the recommended values of emission factors in the literature directly or selected the measured values of adjacent areas without the measured local primary data; hence the final results may not be representative (Song et al. 2012; Zhang et al. 2018). Different forest species or regions with different environments will cause different emission components and release rates of BVOCs (Owen et al. 2002). The difference between the forest species could be the primary factor to determine the BVOCs emission, and different geographical locations own disparate environmental conditions (temperature, PAR) that will also distinguish the emissions eventually. Therefore, the precise emission rates and fluxes of BVOCs from specific forest species in different regions should be obtained before the evaluation of the spatiotemporal effects and interactions of BVOCs on the atmospheric environment. Until present, there has been limited evidence that supports the systematic comparison of the BVOCs measured emission rates of dominant forest species in the Jing-Jin-Ji area. According to the order of volume from high to low, we have selected Platycladus orientalis, Quercus variabilis, Betula platyphylla, Populus tomentosa, Pinus tabuliformis, Robinia pseudoacacia, Ulmus pumila, Salix babylonica and Larix gmelinii as the dominant forest species in the Jing-Jin-Ji area. Based on the field vegetation investigation and measured forest species emission rates, this study used the algorithm in G93 model (Guenther et al. 1993) to estimate the BVOCs emission from dominant forest species in the Jing-Jin-Ji area to establish a more localized emission inventory and eliminate its uncertainty further, analyzed their spatiotemporal distribution characteristics and chemical reactivity to provide a theoretical basis for future air pollution prevention and control measures.

\section{Materials and methods}

\section{Site description}

Jing-Jin-Ji area is located in the North China Plain (Fig. 1), including Beijing, Tianjin, and Hebei $\left(36^{\circ} 05^{\prime}-\right.$ $42^{\circ} 40^{\prime} \mathrm{N}, 113^{\circ} 27^{\prime}-119^{\circ} 50^{\prime} \mathrm{E}$ ), with a total area of about 21.72 ha. This area is surrounded by Bohai Sea in the east, Tai-hang Mountains in the West and Yanshan Mountains in the north, $735 \mathrm{~km}$ from north to south, and $576 \mathrm{~km}$ from east to west, with various terrains and warm temperate continental monsoon climate. The annual average temperature is ranged from 0 to $13^{\circ} \mathrm{C}$ with an average yearly precipitation of $300-800 \mathrm{~mm}$. There are various vegetation types in this area including forest, shrub, grassland, and so on. The sampling sites were selected in the forest parks with abundant plant resources and the collection of the air samples were performed on bright days.

The sampling sites (solid circles) identified as follows: (1) Saihanba National Forest Park; (2) Heilongshan National Forest Park; (3) Labagou Primeval Forest Park; (4)

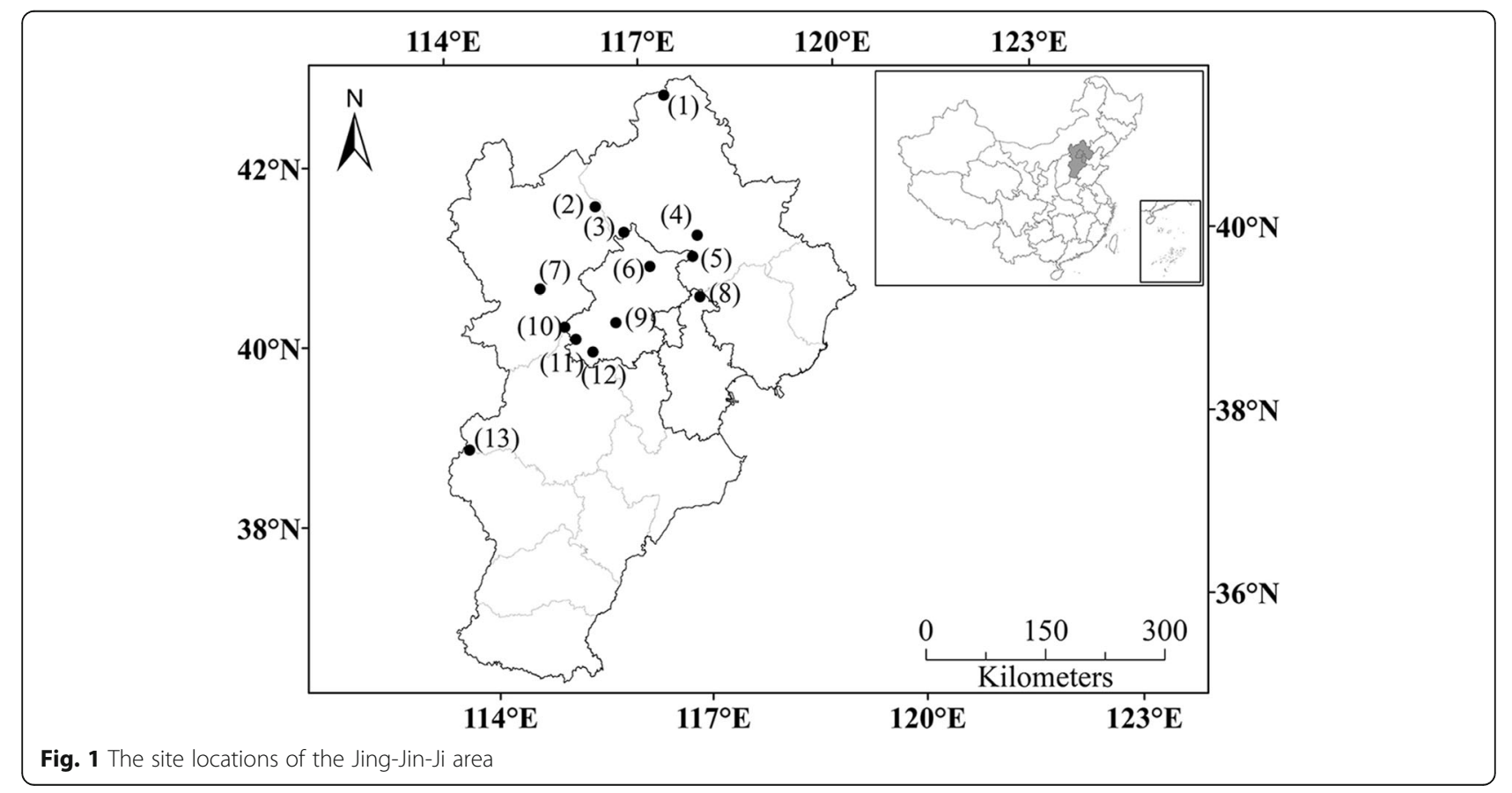


Baicaowa National Forest Park; (5) Wuling Mountain Scenic Spot; (6) Yunmengshan National Forest Park; (7) Huangyangshan Forest Park; (8) Tianjin Jiulongshan National Forest Park; (9) Xishan National Forest Park; (10) Xiaolongmen National Forest Park; (11) Baihuashan National Nature Reserve; (12) Shangfangshan National Forest Park; (13) Wuyuezhai Scenic Spot.

\section{Estimation model of BVOCs emission}

Guenther series models are widely used to estimate BVOCs emission. Guenther combined the latest experimental data to deduce the G93 algorithm in 1993 (Guenther et al. 1993). The model was used to normalize the emission rate of BVOCs under various environmental conditions, including $T=303 \mathrm{~K}$ and $\mathrm{PAR}=1000$ $\mu \mathrm{mol} \cdot \mathrm{m}^{-2} \cdot \mathrm{s}^{-1}$. The BVOCs emitted by dominant forest species were classified as isoprene, monoterpenes, and other VOCs (alcohols, aldehydes, ketones, esters, organic acids, low carbon alkanes and alkenes) in this paper. According to the model of light and temperature effect proposed by G93, the BVOCs emission classified by forest species were estimated respectively. Specific formulas are as follows:

Isoprene:

$$
I=I S \times C L \times C T I
$$

where, $I$ is the emission rate of isoprene (in $\mathrm{C}, \mu \mathrm{g} \cdot \mathrm{g}^{-1}$. $\mathrm{h}^{-1}$ ) under a specific temperature $T(\mathrm{~K})$ and PAR $\left(\mu \mathrm{mol} \cdot \mathrm{m}^{-2} \cdot \mathrm{s}^{-1}\right)$, and $I_{\mathrm{S}}$ is the standard emission rate of isoprene (in $\mathrm{C}, \mu \mathrm{g} \cdot \mathrm{g}^{-1} \cdot \mathrm{h}^{-1}$ ) under standard condition $\left(T=303 \mathrm{~K}, \mathrm{PAR}=1000 \mu \mathrm{mol} \cdot \mathrm{m}^{-2} \cdot \mathrm{s}^{-1}\right) ; C_{\mathrm{L}}$ and $C_{\mathrm{TI}}$ are correction factors for the light and temperature of isoprene, respectively, that can be obtained by Eqs. 2 and 3:

$$
C_{\mathrm{L}}=\alpha C_{\mathrm{L} 1} L / \sqrt{1+\alpha^{2} L^{2}}
$$

where, $\alpha(0.0027)$ and $C_{\mathrm{Ll}}(1.066)$ are empirical constants; $L$ is PAR $\left(\mu \mathrm{mol} \cdot \mathrm{m}^{-2} \cdot \mathrm{s}^{-1}\right)$.

$$
C_{\mathrm{TI}}=\frac{\exp \left[\mathrm{C}_{\mathrm{T} 1}\left(\mathrm{~T}-\mathrm{T}_{\mathrm{S}}\right) / \mathrm{RT}_{\mathrm{S}} \mathrm{T}\right]}{1+\exp \left[\mathrm{C}_{\mathrm{T} 2}\left(\mathrm{~T}-\mathrm{T}_{\mathrm{M}}\right) / \mathrm{RT}_{\mathrm{S}} \mathrm{T}\right]}
$$

where, $R$ is a gas constant $\left(8.314 \mathrm{~J} \cdot \mathrm{K}^{-1} \cdot \mathrm{mol}^{-1}\right) ; T \mathrm{~s}$ is the leaf temperature of the standard state $(303 \mathrm{~K}) . C_{T 1}$ $\left(95,000 \mathrm{~J} \cdot \mathrm{mol}^{-1}\right), \quad C_{T 2} \quad\left(230,000 \mathrm{~J} \cdot \mathrm{mol}^{-1}\right)$ and $T_{\mathrm{M}}$ $(314 \mathrm{~K})$ are empirical constants.

The monoterpenes and other VOCs emission rate in algorithm G93 can be calculated using Eqs. 4 and 5:

$$
\begin{aligned}
& M=M_{\mathrm{S}} C_{\mathrm{TM}} \\
& C_{\mathrm{TM}}=\exp \left[\beta\left(\mathrm{T}-\mathrm{T}_{\mathrm{S}}\right)\right]
\end{aligned}
$$

where, $M$ is the emission rate of monoterpenes and other VOCs (in C, $\mu \mathrm{g} \cdot \mathrm{g}^{-1} \cdot \mathrm{h}^{-1}$ ) under a certain temperature $T(\mathrm{~K}) ; M_{\mathrm{S}}$ is the standard emission rate of monoterpenes and other VOCs (in $\mathrm{C}, \mu \mathrm{g} \cdot \mathrm{g}^{-1} \cdot \mathrm{h}^{-1}$ ) under standard condition $(T \mathrm{~s}=303 \mathrm{~K}) ; C_{\mathrm{TM}}$ is the correction factor for the temperature of monoterpenes and other VOCs; $\beta\left(0.09 \mathrm{~K}^{-1}\right)$ is empirical constant.

Experimental results showed that the emission rate of isoprene is mainly controlled by leaf temperature and PAR. However, the main factor affecting monoterpenes and other VOCs emission by plants is temperature (Guenther et al. 1993). Therefore, the emission estimation method of isoprene is:

$$
E_{\mathrm{ISOP}}=I_{\mathrm{S}} \times B \times C_{\mathrm{TI}} \times C_{\mathrm{L}}
$$

The emission estimation method of monoterpenes and other VOCs is:

$$
E_{\mathrm{MONO}}, E_{\mathrm{OVOC}}=M_{\mathrm{S}} \times B \times C_{\mathrm{TM}}
$$

where, $E_{\mathrm{ISOP}}$ is the emission of isoprene (in $\mathrm{C}, \mu \mathrm{g} \cdot \mathrm{h}^{-1}$ ); $E_{\mathrm{MONO}}$ and $E_{\mathrm{OVOC}}$ are the emissions of monoterpenes and other VOCs (in $\mathrm{C}, \mu \mathrm{g} \cdot \mathrm{h}^{-1}$ ), respectively; and $B$ is the leaf biomass (dry weight, g) of each species. The required meteorological data (temperature and PAR of every month in the Jing-Jin-Ji area in 2017) can be retrieved from MODIS satellite product data published on the NASA website (https://modis.ornl.gov/data.html).

\section{Determination of model parameters \\ Emission rates}

Air samples were collected using a dynamic headspace method (Jing et al. 2020). The sampling system consists of a transparent Teflon film sampling bag $(10 \mathrm{~L})$, an atmospheric sampler (LaoDong QC-1 S, Beijing Municipal Institute of Labor Protection, China), two drying towers (filled with activated carbon particles that have been pre-dried for more than $5 \mathrm{~h}$ and allochroic silica gel, respectively), an ozone removal column (Cleanert KI: $1.4 \mathrm{~g} / 2.5 \mathrm{~mL}$, Agela Technologies, China) and an adsorption tube (tube type: stainless steel tube, Camsco company, USA, filled with Carbograph 2 (60/80), Carbograph 1 (40/60) and Carbosieve SIII (60/80) adsorbents). All parts were connected with polytetrafluoroethylene (PTFE) tubes (Fig. 2). Before sampling, the adsorption tubes were purged and activated at $270{ }^{\circ} \mathrm{C}$ for $2 \mathrm{~h}$ under high-purity $\mathrm{N}_{2}$ (purity: 99.99\%), then stored under cold storage at $4{ }^{\circ} \mathrm{C}$. When sampling, the branches with healthy foliage were selected and enclosed in the sampling bag. First, the air in the sampling bag was extracted, and then the air that has passed through the two drying towers and the ozone adsorption column was pumped in. Finally, the adsorption tube was connected to form a closed loop. The air samples were collected at a flow rate of $150 \mathrm{~mL} \cdot \mathrm{min}^{-1}$ for $1 \mathrm{~h}$. The temperature and relative humidity in the sampling bag 


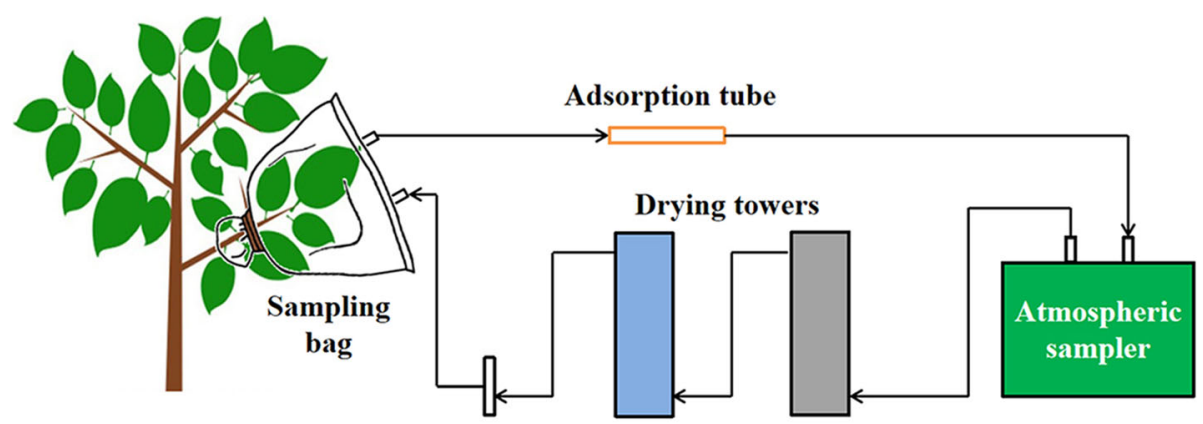

Ozone removal column

Fig. 2 Flow chart of dynamic headspace sampling

were measured by a hand meteorometer instrument (NK4500, Kestrel, USA). The PAR in the sampling environment was measured using a light quantum meter (3415FQF, Spectrum, USA). Table 1 shows the sampling dates and averaged environmental conditions during the sampling. After collection, the adsorption tube was stored in the refrigerator at $4{ }^{\circ} \mathrm{C}$ and analyzed within one week.

The air samples were desorbed on PE TurboMatrix (650ATD-Clarus600) and analyzed by thermal desorption gas chromatography-mass spectrometry (GC-MS, Agilent 6890 , USA). Most of the organics in the adsorption tube were released after $5 \mathrm{~min}$ in a thermal resolver at $260{ }^{\circ} \mathrm{C}$, and then the substances were adsorbed into the cold trap $\left(-25^{\circ} \mathrm{C}\right)$. The substances condensed in the cold trap were quickly heated from 260 to $300{ }^{\circ} \mathrm{C}$ at a heating rate of $40{ }^{\circ} \mathrm{C} \cdot \mathrm{s}^{-1}$ then transferred to the chromatograph for further separation and analysis. The column used was DB$5 \mathrm{MS}$ (column height of $30 \mathrm{~m}$, inner diameter of $0.25 \mathrm{~mm}$, pore diameter of $0.25 \mu \mathrm{m}$ ) and the carrier gas used was helium $\left(1.0 \mathrm{~mL} \cdot \mathrm{min}^{-1}\right)$. The heating process was divided into three stages at $40{ }^{\circ} \mathrm{C}, 160$ and $270{ }^{\circ} \mathrm{C}$ that maintained at 2,2 and $3 \mathrm{~min}$, respectively, with a heating rate of $4{ }^{\circ} \mathrm{C} \cdot \mathrm{min}^{-1}$. The mass spectrometer adopts an electron bombardment ionization mode with energy of $70 \mathrm{eV}$ and a scanning atomic mass range of 30-500 amu. The compounds were retrieved from the database of National Institute of Standards and Technology (NIST) based on their retention times and specific charge and quantified using the standard external method. The standard gases used were as follows: Photochemical Assessment Monitoring Stations (PAMS) (Spectra/Linde: 57$)$ and $n$-hexane, isoprene, $\alpha$-pinene, $\beta$-pinene, $\alpha$-phellandrene, 3 -carene, $\beta$ myrcene, $\alpha$-terpinene, limonene, $\gamma$-terpinene, and ocimene made by the National Institute of Metrology, China. The TCT-GC-MS instrument has been calibrated using standard gases. The recovery rate of standard addition was between 90 and $110 \%$ and coefficients of variance were less than $5 \%$.

The emission rates of dominant forest species in the Jing-Jin-Ji area were respectively calculated according to the following Equation:

$$
\mathrm{ER}=\frac{m}{t \times M}
$$

where, ER is the chemical substance emission rate of each forest species (in $\mathrm{C}, \mu \mathrm{g} \cdot \mathrm{g}^{-1} \cdot \mathrm{h}^{-1}$ ); $m$ is the mass of

Table 1 Sampling dates and averaged environmental conditions during the samplings in 2017

\begin{tabular}{|c|c|c|c|c|c|}
\hline Sampling Date & Binomial name & Region & ${ }^{\text {aPAR }}\left(\mu \mathrm{mol} \cdot \mathrm{m}^{-2} \cdot \mathrm{s}^{-1}\right)$ & ${ }^{\mathrm{b}} T\left({ }^{\circ} \mathrm{C}\right)$ & ${ }^{{ }^{c} \mathrm{RH}(\%)}$ \\
\hline $08 / 23-08 / 24$ & Salix babylonica & $(2) /(7) /(9)$ & 938 & 32.5 & 23.7 \\
\hline 08/29-08/31 & Pinus tabuliformis & $(1) /(5) /(9) /(11)$ & 1963 & 33.1 & 23.9 \\
\hline 08/29-08/31 & Populus tomentosa & $(1) /(4) /(5) /(7) /(8)$ & 1369 & 34.0 & 27.2 \\
\hline 07/29-07/31 & Platycladus orientalis & $(4) /(5) /(7) /(8) /(9)$ & 1606 & 34.2 & 27.4 \\
\hline 08/29-08/30 & Robinia pseudoacacia & $(5) /(7) /(13)$ & 1206 & 32.8 & 23.2 \\
\hline 06/20-06/21 & Ulmus pumila & $(2) /(4) /(7)$ & 1537 & 37.1 & 23.6 \\
\hline 06/05-06/07 & Larix gmelinii & $(1) /(4) /(5) /(6) /(10)$ & 1629 & 29.1 & 19.9 \\
\hline 07/01-07/02 & Quercus variabilis & $(8) /(9) /(12)$ & 1059 & 34.5 & 22.6 \\
\hline 07/27-07/28 & Betula platyphylla & $(1) /(3) /(10) /(12) /(13)$ & 875 & 31.0 & 24.3 \\
\hline
\end{tabular}

(1)-(13): The specific name of sampling place is shown in the note of Fig. 1

${ }^{a} P A R$ Photosynthetically active radiation

${ }^{\mathrm{b}} T$ Temperature in the bag

${ }^{\mathrm{c}} \mathrm{RH}$ Relative humidity 
the chemical substance in adsorption tube (in C, $\mu \mathrm{g}$ ); $t$ is the sampling time (h); $M$ is the leaf biomass of forest species in the sapmling bag (dry weight, g).

\section{Leaf biomass calculation}

The leaf biomass data in the Jing-Jin-Ji area were obtained using the method of volume and biomass conversion. The statistical method of subdividing species enables them to correspond to more appropriate emission factors and biomass, by considering the difference of the same species in different regions. Based on the volumes obtained from the national forest resource inventory, the leaf biomass of the dominant forest species was calculated as follows:

$$
B=\frac{V \times D_{\mathrm{T}}}{P_{\mathrm{T}}} \times P_{\mathrm{L}}
$$

where $B$ is leaf biomass of forest species (dry weight, g); $V$ is tree volume $\left(\mathrm{m}^{3}\right) ; D_{\mathrm{T}}$ is the basic density of tree trunk (the ratio of absolute dry wood mass to raw wood volume); $P_{\mathrm{T}}$ and $P_{\mathrm{L}}$ are the proportion of stem and leaf in the total biomass of tree layer respectively. The data of $P_{\mathrm{T}}, P_{\mathrm{L}}$ and $D_{\mathrm{T}}$ were retrieved from literature (Wang et al. 2001). In this study, the proportion of trunk density, leaf and stem biomass to the total biomass of dominant forest species in the Jing-Jin-Ji area were presented in Table A1. Tree volumes data were mainly based on national forest resources survey data, checked and supplemented by forestry network and field survey.

\section{Methods of chemical activity evaluation}

Different BVOCs components have different chemical compositions and physical properties, thus the atmospheric chemical reaction capacity is different (Goldan et al. 2004). The chemical reactivity of different components and their ability to generate ozone can provide reference for the control measures of BVOCs. This study adopted two methods namely the maximum incremental reactivity (MIR) method and the $\cdot \mathrm{OH}$ reaction rate $\left(\mathrm{L}^{\mathrm{OH}}\right)$ method, to comprehensively analyze the chemical activity of the BVOCs components of dominant forest species in the Jing-Jin-Ji area.

Ozone formation potential (OFP) was used to evaluate the potential release of BVOCs into the atmosphere under optimal reaction conditions for ozone generation and measure the reactivity of different BVOCs components (Carter 1991). The calculation of OFP is shown in Eq. 10:

$$
\mathrm{OFP}_{i}=\mathrm{MIR}_{i} \times C_{i}
$$

where $\mathrm{OFP}_{i}$ is the ozone generation potential of each component $\left(\mu \mathrm{g} \cdot \mathrm{m}^{-3}\right) ; \mathrm{MIR}_{i}$ is the maximum incremental response factor of each component $\left(\left(\mathrm{g} \mathrm{O}_{3}\right) /(\mathrm{g}\right.$ VOCs $\left.)\right)$
(Carter 2008); $C_{i}$ is the mass concentration of each component $\left(\mu \mathrm{g} \cdot \mathrm{m}^{-3}\right)$.

The chemical reaction of the troposphere during the daytime is mainly $\mathrm{OH}$ radicals $(\cdot \mathrm{OH})$. The volatile organic compounds will first react with $\cdot \mathrm{OH}$, and then react with $\mathrm{O}_{2}$ and $\mathrm{NO}_{x}$ under light condition to generate new free radicals to initiate the chain reaction. The first reaction is a key step that determines the rate of atmospheric photochemical reaction chain, so the consumption rate of $\mathrm{OH}$ can be used to evaluate the photochemical activity of BVOCs. The calculation is shown in Eq. 11:

$$
L_{i}^{\mathrm{OH}}=K_{i}^{\mathrm{OH}} \times[\mathrm{BVOCs}]_{i}
$$

where $L_{i}{ }^{\mathrm{OH}}$ is the consumption rate of each component to atmospheric $\cdot \mathrm{OH}\left(\mathrm{s}^{-1}\right) ; K_{i}^{\mathrm{OH}}$ is the reaction rate constant between each component and atmospheric $\cdot \mathrm{OH}$ $\left(\mathrm{cm}^{3} \cdot \mathrm{molecul}^{-1} \cdot \mathrm{s}^{-1}\right)$ (https://kinetics.nist.gov/kinetics/ index.jsp); $[\mathrm{BVOCs}]_{i}$ is the atmospheric molecular concentration of every component (molecule $\cdot \mathrm{cm}^{-3}$ ).

\section{Results and discussion}

\section{Emission budgets and compositions of BVOCs}

According to Eqs. 6 and 7, based on the measured standardized emission factors of each forest species, leaf biomass data obtained from the forest resource data and field survey, and the annual meteorological data through the NASA website, the annual BVOCs emission of every component of each forest species in the Jing-Jin-Ji area was estimated. BVOCs emitted from dominant forest species were divided into isoprene, monoterpenes (including $\alpha$ pinene, $\beta$-pinene, $\beta$-myrcene, limonene, 3 -carene and so on), and other VOCs (OVOCs) (Table A2). The normalized emission rates of BVOCs in dominant forest species in the Jing-Jin-Ji area are tabulated in Table 2. The total annual emission of BVOCs from dominant forest species in the Jing-Jin-Ji area was estimated to be $70.8 \mathrm{Gg}$ C.year ${ }^{-1}$, including $40.5 \%$ (28.7 Gg C.year ${ }^{-1}$ ) of isoprene, $36.0 \%$ (25.5 Gg C.year ${ }^{-1}$ ) of monoterpenes and $23.4 \%$ (16.6 Gg C.year ${ }^{-1}$ ) of other VOCs, respectively.

Different forest species can produce various components of BVOCs. Figure 3 shows each component and proportion of BVOCs emitted by nine dominant forest species in the Jing-Jin-Ji area. Isoprene was emitted as the main component from broadleaf trees such as Betula platyphylla, Quercus variabilis, and Salix babylonica. Aside from isoprene, some of the broadleaf trees (i.e. Populus tomentosa, Robinia pseudoacacia, Ulmus pumila) and most coniferous trees like Platycladus orientalis, Pinus tabuliformis, and Larix gmelinii released monoterpenes such as $\alpha$-pinene, $\beta$-pinene, $\beta$-myrcene and limonene. As shown in Fig. A1, the isoprene emission was mainly detected from Quercus variabilis and 
Table 2 Normalized emission rates of biogenic volatile organic compounds (BVOCs) in dominant forest species in the Jing-Jin-Ji area $\left(\mu \mathrm{g} \cdot \mathrm{g}^{-1} \cdot \mathrm{h}^{-1}\right)$

\begin{tabular}{lllllllll}
\hline Forest species & Isoprene & a-pinene & $\boldsymbol{\beta}$-pinene & $\boldsymbol{\beta}$-myrcene & limonene & 3-carene & ${ }^{\text {a OVOCs }}$ & ${ }^{\text {b TVOCs }}$ \\
\hline Platycladus orientalis & $0.046 \pm 0.017$ & $2.329 \pm 0.096$ & $0.097 \pm 0.015$ & $0.364 \pm 0.021$ & $0.235 \pm 0.046$ & $1.362 \pm 0.321$ & $1.498 \pm 0.537$ & $5.931 \pm 0.635$ \\
Robinia pseudoacacia & $9.767 \pm 2.043$ & $0.329 \pm 0.067$ & $0.236 \pm 0.047$ & $0.090 \pm 0.017$ & $0.142 \pm 0.008$ & $0.051 \pm 0.004$ & $1.870 \pm 0.649$ & $12.485 \pm 2.145$ \\
Betula platyphylla & $2.624 \pm 0.432$ & $0.010 \pm 0.004$ & nd & nd & nd & nd & $1.497 \pm 0.529$ & $4.131 \pm 0.683$ \\
Quercus variabilis & $17.017 \pm 2.492$ & nd & nd & nd & nd & nd & $0.987 \pm 0.475$ & $18.004 \pm 2.537$ \\
Salix babylonica & $22.110 \pm 3.347$ & nd & nd & nd & nd & nd & $1.205 \pm 0.486$ & $23.315 \pm 3.382$ \\
Populus tomentosa & $4.810 \pm 1.057$ & $0.173 \pm 0.044$ & $0.018 \pm 0.003$ & $0.104 \pm 0.007$ & $0.095 \pm 0.042$ & $0.001 \pm 0.001$ & $1.260 \pm 0.492$ & $6.461 \pm 1.168$ \\
Pinus tabuliformis & $1.157 \pm 0.240$ & $2.065 \pm 0.378$ & $0.014 \pm 0.002$ & $2.576 \pm 0.344$ & $1.180 \pm 0.233$ & $0.007 \pm 0.002$ & $1.435 \pm 0.762$ & $8.434 \pm 0.977$ \\
Ulmus pumila & $0.417 \pm 0.090$ & $0.117 \pm 0.089$ & nd & $0.132 \pm 0.019$ & nd & nd & $1.263 \pm 0.358$ & $1.929 \pm 0.380$ \\
Larix gmelinii & $0.006 \pm 0.002$ & $5.195 \pm 1.046$ & $2.152 \pm 0.928$ & nd & nd & nd & $1.506 \pm 0.951$ & $8.859 \pm 1.691$ \\
\hline
\end{tabular}

nd not detected

${ }^{a} O V O C s$ other VOCs

${ }^{\mathrm{b}}$ TVOCS total VOCs

Populus tomentosa that recording at $41.2 \%$ and $31.1 \%$, respectively. On the other hand, Platycladus orientalis and Pinus tabuliformis are the significant emitters of monoterpenes, providing $56.1 \%$ and $36.0 \%$, respectively. Therefore, it was revealed that these four forest species are the main contributors to BVOCs emission in the Jing-Jin-Ji area: $19.3 \mathrm{Gg} \mathrm{C} \cdot \mathrm{year}^{-1}(27.2 \%)$ from Platycladus orientalis, $14.0 \mathrm{Gg} \mathrm{C} \cdot \mathrm{year}^{-1}(19.8 \%)$ from Quercus variabilis, 13.4 Gg C.year ${ }^{-1}(18.9 \%)$ from Populus

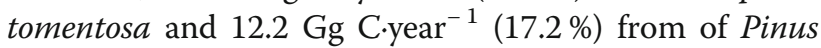
tabuliformis (Table A2).

\section{Monthly and seasonal variations}

As shown in Eqs. 6 and 7, by multiplying the measured standardized emission factors of each forest species, monthly leaf biomass data obtained from the forest resource data and field survey, and the monthly meteorological data through the NASA website in 2017, the monthly and seasonal BVOCs emission of every component of each forest species in the Jing-Jin-Ji area were estimated. Table A3 and Fig. 4 indicate that the BVOCs emission and composition in the Jing-Jin-Ji area demonstrate significant variations for both monthly and seasonal. A distinct unimodal change with the month for the emissions of BVOCs was observed.

The total BVOCs emission was peaked in July with a total amount of $15.8 \mathrm{Gg} \mathrm{C} \cdot \mathrm{year}^{-1}$, while recorded a minimum value in January of $0.4 \mathrm{Gg} C \cdot \mathrm{year}^{-1}$ with two orders of magnitude difference. In January, the emission of isoprene from vegetation hit the lowest point at $1.9 \times$
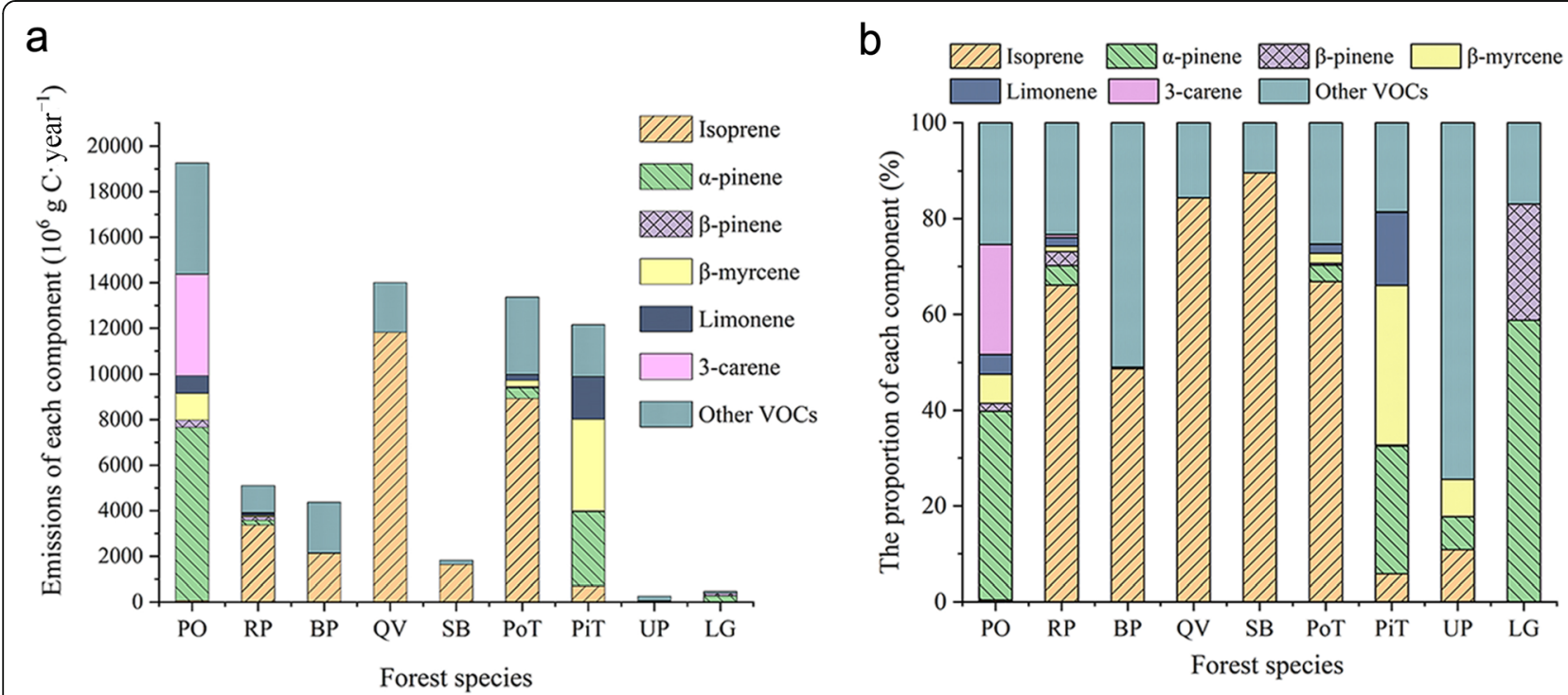

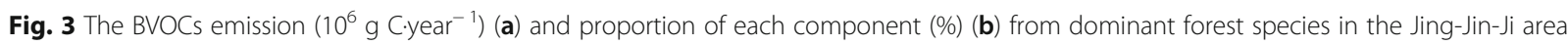
(BP: Betula platyphylla; QV: Quercus variabilis; UP: Ulmus pumila; POT: Populus tomentosa; RP: Robinia pseudoacacia; PO: Platycladus orientalis; PiT: Pinus tabuliformis; SB: Salix babylonica; LG: Larix gmelinii) 


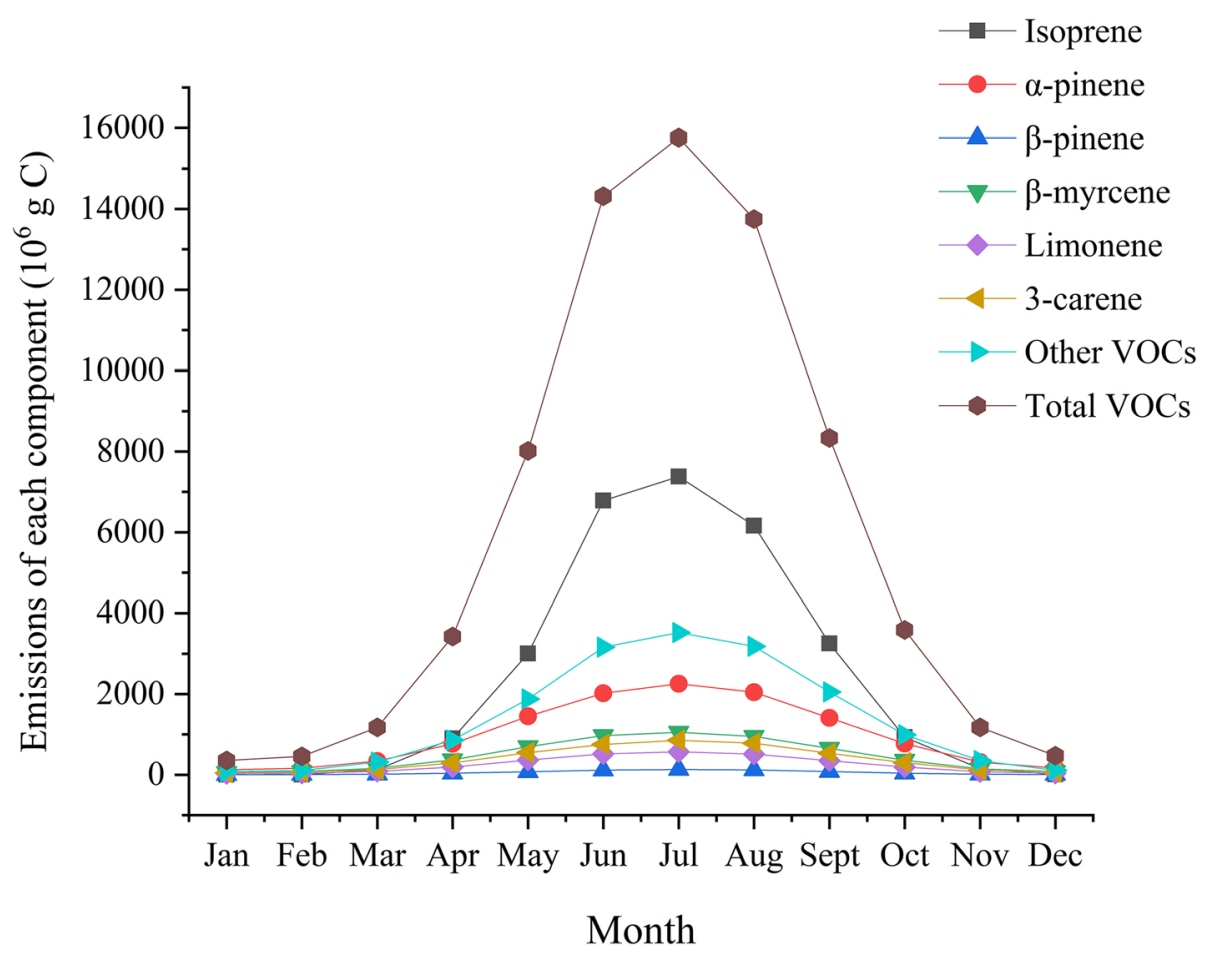

Fig. 4 The monthly BVOCs emission from dominant forest species in the Jing-Jin-Ji area $\left(10^{6} \mathrm{~g} \mathrm{C}\right)$

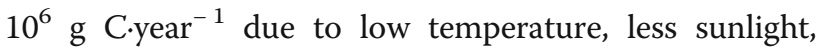
and the limited leaves of biomass. In contrast, the emission of isoprene achieved the highest point at $7.4 \mathrm{Gg}$ C.year ${ }^{-1}$ in July when the air temperature was high with presence of strong sunlight, and abundant leaves of biomass. Nevertheless, the emission of isoprene fluctuated in other months between the maximum and minimum values obtained. The same trend was obtained from the emission of monoterpenes and other VOCs in which the highest emission was recorded in July while the lowest emission was detected in January.

Overall, the total BVOCs emission was peaked in summer (June, July, and August) and bottomed out in winter (December, January and February). In spring, the BVOCs emission showed an upward trend in which the isoprene was increased the most. Despite the emissions of both monoterpenes and other VOCs also increased, the values recorded were comparatively lower than the isoprene that could be due to the more significant influence of sunlight and temperature on isoprene. Under these conditions in spring, the vegetation was still in the growing stage where the leaves were immature with regular enzyme activity. Therefore, the emission of BVOCs in spring only accounted for $17.8 \%$ in the whole year. Comparatively, the average daily temperature and sunshine time were significantly increased in summer than that in spring. Under these conditions, the vegetation leaves reached the mature stage and grown with maximum leaf area; consequently, the highest enzyme activity was achieved. As a result, high emission of BVOCs were observed in summer with the emission of $43.8 \mathrm{Gg} \mathrm{C} \cdot \mathrm{year}^{-1}$ that accounting for $61.9 \%$ of the total annual emissions. In autumn, the temperature difference was noticeable. The leaves were transformed from the mature leaves to the decaying leaves. Therefore, the emission of BVOCs showed a decreasing trending in September, followed by a sharp decrease in October, and finally constant in November. The total emission of BVOCs recorded in autumn at only $18.5 \%$. Due to low temperatures and limited solar irradiation in winter, the emission of BVOCs reached the lowest value of the year at only $1.8 \%$.

\section{Spatial distribution}

The leaf biomass data of each dominant forest species from 13 cities in the Jing-Jin-Ji area were obtained based on the forest resources data and field survey, while the annual meteorological data of each city were retrieved from the NASA website. Then, the standardized emission factors, leaf biomass data and meteorological factors were calculated according to Eqs. 6 and 7 to obtain the annual BVOCs emission data of each forest species in 13 cities of the Jing-Jin-Ji area in 2017. The BVOCs emission of dominant forest species in 13 cities (Beijing, Tianjin, Baoding, Cangzhou, Chengde, Handan, Hengshui, Langfang, Qinhuangdao, Shijiazhuang, Tangshan, 
Xingtai, Zhangjiakou) throughout 2017 were calculated to study the spatial distribution of BVOCs emission in the Jing-Jin-Ji area. As shown in Table A4 and Fig. 5, the BVOCs emission fluxes and the compositions in the Jing-Jin-Ji area demonstrate an apparent spatial distribution. Given that Chengde and Beijing have high coverage of vegetation, and the presence of dominant species (Betula platyphylla, Quercus variabilis, Populus tomentosa and Pinus tabulaeformis) in Wuling Mountain Reserve and Saihanba Forest Farm in Chengde showed higher BVOCs emission rates. Therefore, Chengde contributed the highest BVOCs emission of dominant forest species in the Jing-Jin-Ji area with $20.4 \mathrm{Gg} \mathrm{C} \cdot$ year $^{-1}$ (28.8\%), followed by Beijing with a total discharge of $17.6 \mathrm{Gg} \mathrm{C}$.year ${ }^{-1}$ (24.9\%). The remaining proportion of BVOCs emission was detected from Baoding, Tangshan, Hengshui and Zhangjiakou. Furthermore, the detected BVOCs emission of Cangzhou (0.4 Gg C.year ${ }^{-1}, 0.6 \%$ ) and Langfang (0.5 $\mathrm{Gg} \mathrm{C} \cdot$ year $^{-1}, 0.8 \%$ ) were less than the others due to their smaller city area and lower vegetation coverage. In terms of compositions (Fig. A2), Chengde presents the largest isoprene emission with $26.8 \%$ (7.7 $\mathrm{Gg} \mathrm{C} \mathrm{year}^{-1}$ ) of the total isoprene emissions released by dominant forest species in the Jing-Jin-Ji area. This could probably due to the extensive vegetation coverage of deciduous trees with high isoprene emissions such as Quercus variabilis. Asides from Chengde, Beijing also shows a high emissions of monoterpenes $(9.4 \mathrm{Gg}$ $C \cdot$ year $^{-1}$ ) that accounting for $36.9 \%$ of the total monoterpenes emissions. This could be attributed to the emission of $\alpha$-pinene and $\beta$-myrcene from coniferous such as Platycladus orientalis and Pinus tabuliformis, which could also explain the highest emissions detected for Chengde in spring, summer, and autumn, but lower than Beijing particularly in winter. Chengde possesses the most substantial difference in emissions in winter and summer because the dominant forest species here are mostly deciduous trees. The low temperature and less sunshine in winter would have caused the leaf biomass of deciduous trees to emit lower BVOCs; thus the emission was reduced significantly (Fig. 6). In general, the distribution of BVOCs emission fluxes was highly consistent with the distribution of vegetation.

Overall, the BVOCs emission estimated in this study were much lower than those estimated by Klinger et al. (2002) (Table 3). It is due to the difference in the scope of the study objects where this study focused on the specific dominant forest species while Klinger et al. (2002) covered all species in this area, including grasslands, shrublands, forests, and peatlands.

\section{Chemical activity evaluation}

The contribution of BVOCs to atmospheric chemical reaction depends on the level of its emissions and closely related to their chemical activity. Since the olefins with double bonds are more active compounds in addition to the main BVOCs components released by dominant forest species in the Jing-Jin-Ji area are isoprene and monoterpenes, the chemical activity of isoprene and monoterpenes by the maximum incremental reactivity

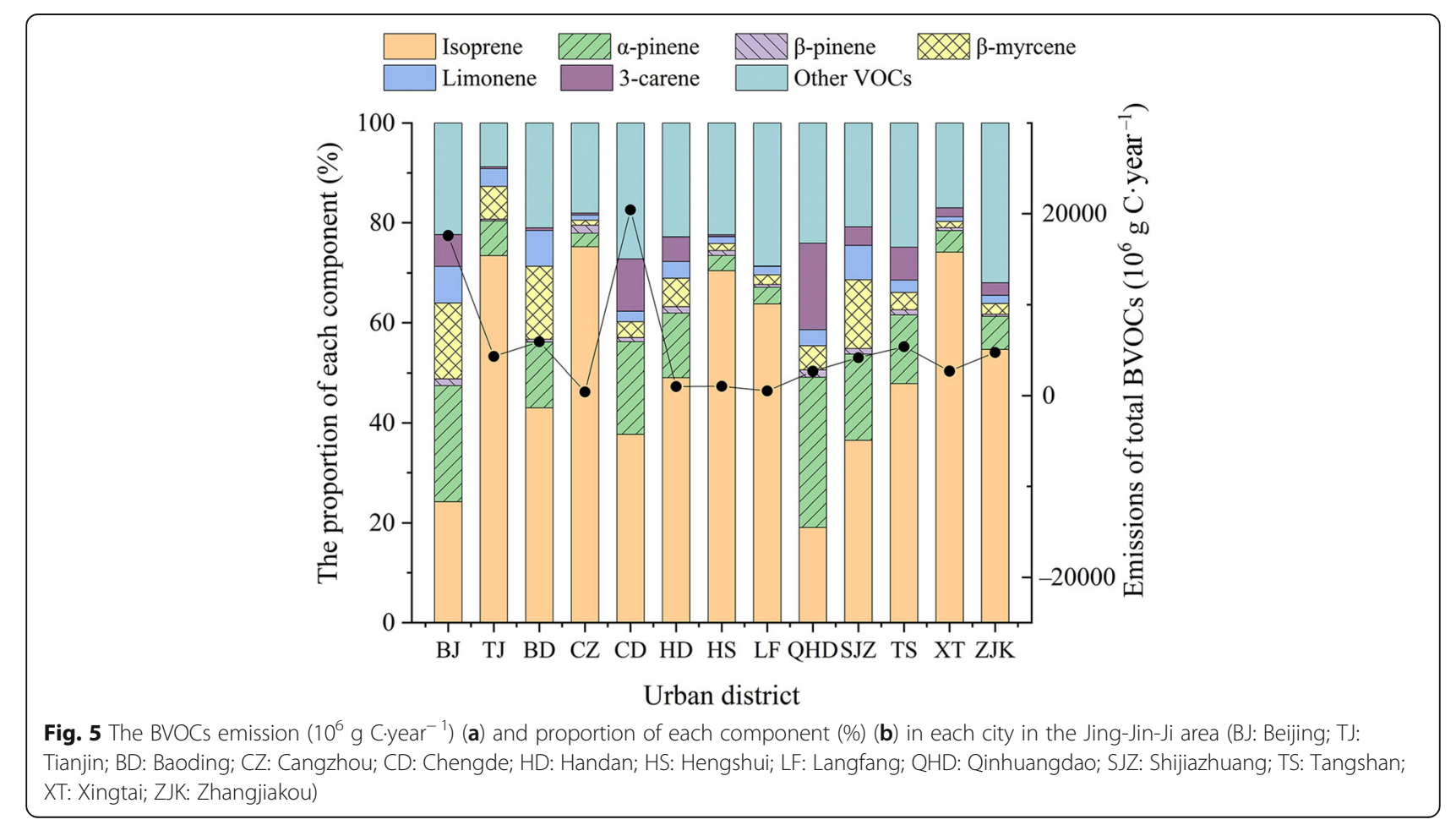



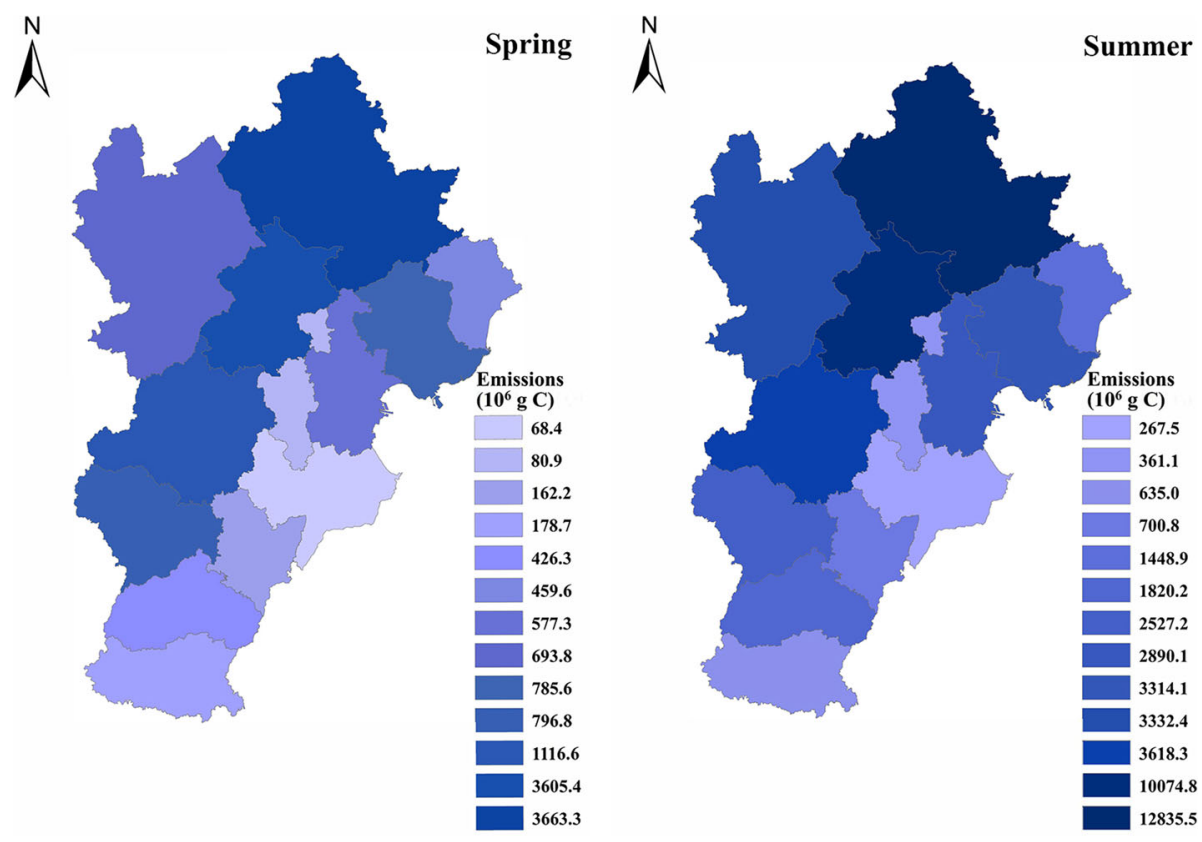

$\bigwedge^{N}$

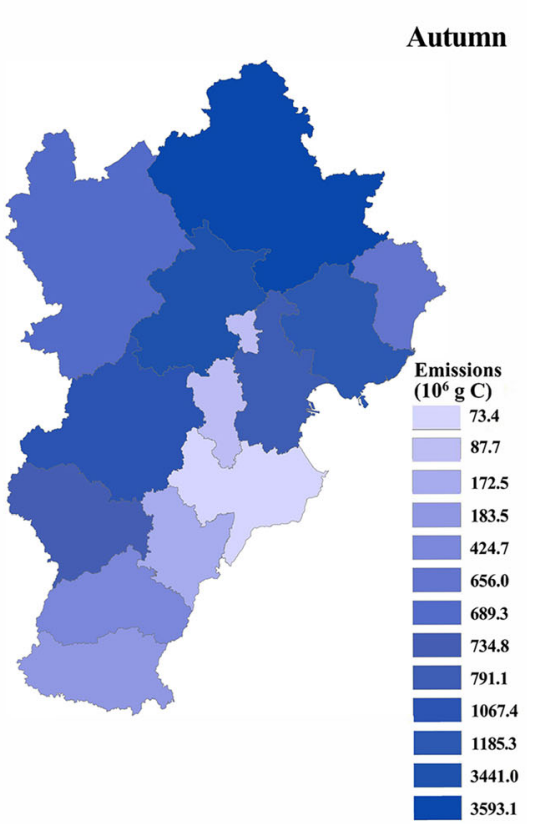

$\stackrel{N}{\Lambda}$

Winter

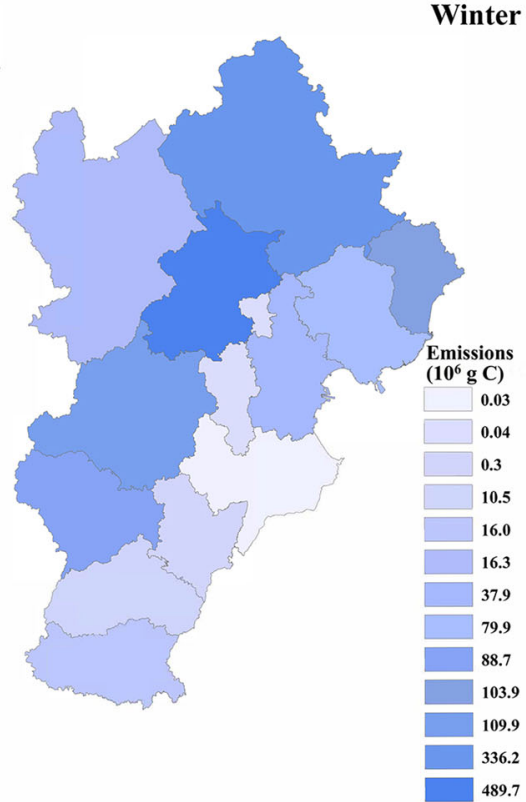

Fig. 6 The seasonal BVOCs emission distribution of dominant forest species in the Jing-Jin-Ji area $\left(10^{6} \mathrm{~g} \mathrm{C}\right)$

(MIR) method and the $\cdot \mathrm{OH}$ reaction rate $\left(\mathrm{L}^{\mathrm{OH}}\right)$ method were analyzed comprehensively. Figure 7 shows the OFP and $\mathrm{L}_{i}{ }^{\mathrm{OH}}$ values and activity contribution rates of every dominant forest species. Overall, the activity contribution rate of isoprene and monoterpenes of each species calculated using two methods are basically consistent. Among them, the OFP values of Robinia pseudoacacia, Populus tomentosa and Quercus variabilis obtained by the MIR method were higher, followed by Betula platyphylla and Pinus tabuliformis while the lowest OFP value was obtained for Ulmus pumila. The forest species with higher $\mathrm{L}_{i}{ }^{\mathrm{OH}}$ value obtained by the $\mathrm{L}^{\mathrm{OH}}$ method were Robinia pseudoacacia, Populus tomentosa, Platycladus orientalis, Pinus tabuliformis and Quercus variabilis while Larix gmelinii had the lowest $\mathrm{L}_{i}{ }^{\mathrm{OH}}$ value. The difference between the two methods was due to their different principles in which the $\mathrm{L}^{\mathrm{OH}}$ method reflects the reactivity by calculating the ability of BVOCs and $\mathrm{OH}$ radical to produce $\mathrm{RO}_{2}$ without considering the influence of other subsequent reactions. Although the MIR 
Table 3 Comparison of estimated BVOCs emission in different regions

\begin{tabular}{|c|c|c|c|c|}
\hline \multirow[t]{2}{*}{ Regions } & \multicolumn{2}{|c|}{ Emissions $\left(10^{9} \mathrm{~g} \mathrm{C}^{-}\right.$year $\left.^{-1}\right)$} & \multirow[b]{2}{*}{${ }^{\mathrm{a} O V O C s}$} & \multirow[b]{2}{*}{ References } \\
\hline & Isoprene & Monoterpenes & & \\
\hline Beijing & 13.9 & 7.8 & 26.3 & Klinger et al. (2002) \\
\hline Beijing & 4.3 & 9.4 & 4.0 & This study \\
\hline Tianjin & 2.6 & 1.4 & 22.2 & Klinger et al. (2002) \\
\hline Tianjin & 3.2 & 0.8 & 0.4 & This study \\
\hline Hebei & 99.2 & 50.9 & 321.0 & Klinger et al. (2002) \\
\hline Hebei & 21.3 & 15.3 & 12.3 & This study \\
\hline
\end{tabular}

${ }^{\mathrm{a} O V O C s}$ other VOCs

method considers a series of responses of BVOCs, the lack of some MIR coefficients also affect the results. Based on the two approaches, Robinia pseudoacacia, Populus tomentosa, Quercus variabilis and Pinus tabulaeformis are the dominant forest species that contribute higher BVOCs reaction activity in the Jing-Jin-Ji area. Among them, Robinia pseudoacacia, Populus tomentosa and Quercus variabilis have higher reactivity due to their higher isoprene activity contribution rate. The OFP and $\mathrm{L}^{\mathrm{OH}}$ value of Robinia pseudoacacia, Populus tomentosa, Quercus variabilis were $156.76 \mu \mathrm{g} \cdot \mathrm{m}^{-3}$ and $138.36 \times 10^{5}, 87.19 \mu \mathrm{g} \cdot \mathrm{m}^{-3}$ and $78.86 \times 10^{5}, 87.19 \mu \mathrm{g} \cdot \mathrm{m}^{-3}$ and $78.86 \times 10^{5}$, respectively. In addition, Pinus tabulaeformis was detected with a higher activity contribution rate of monoterpenes, especially $\beta$-myrcene, limonene, and $\alpha$ pinene, hence the OFP and $\mathrm{L}^{\mathrm{OH}}$ were detected at $43.63 \mu \mathrm{g} \cdot \mathrm{m}^{-3}$ and $54.67 \times 10^{5}$, respectively.

\section{Uncertainty in BVOCs emission estimates}

Since the emissions of BVOCs by vegetation are influenced by multiple factors, the uncertainty needs to be taken into consideration for the estimation. The primary sources of uncertainty in BVOCs emission estimation include emission factors, leaf biomass, vegetation distribution, model algorithm and meteorological parameters. Estimation of total BVOCs emission released by vegetation on the ground in the Jing-Jin-Ji area was studied using different algorithms and data sources. Different models, emission factors or vegetation type data would produce considerably different emissions (approximately two-fold) (Carlton and Baker 2011; Hogrefe et al. 2011; Chen et al. 2018). Given the above, the BVOCs emission estimated in this study are based on the field vegetation investigation and measured forest species emission rates as an effort to eliminate the uncertainties further. However, the emission rates obtained through experiments are mostly related to plant physiological conditions. Hence, the differences in the values could be due to uncertainty or uncontrollable stressors, environmental conditions, or genetically related metabolic processes (Loreto et al. 2009; Monson et al. 2013). For the sampling method, the dynamic headspace method used in this study has more air circulation than the static system, thus the real existing environment of plants can be maintained in good condition. However, the disturbance to plants during the process and the unrealistic high concentration of $\mathrm{H}_{2} \mathrm{O}$ caused by transpiration may interfere with the leaf stomata; consequently the emissions could be impacted (Ortega et al. 2008). Moreover, the rapid reactivity of BVOCs would also affect the deviation of flux and the analysis performed by the GC-MS instrument may also possess potential measurement errors. As for the emission factors in this study, the influence of solar radiation on monoterpene emissions is not
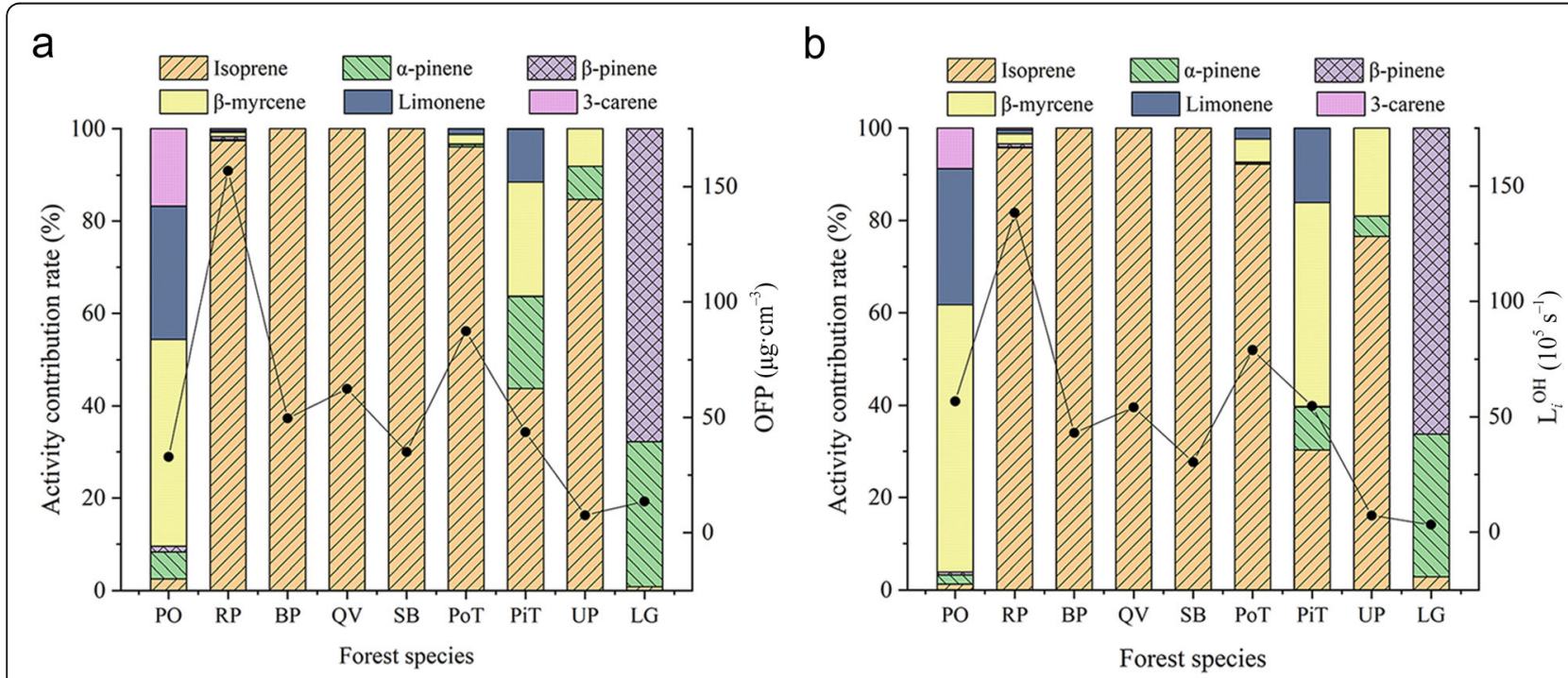

Fig. 7 The reaction activity and activity contribution rate of BVOCs of dominant tree species in the Jing-Jin-Ji area calculated by MIR method (a) and $\mathrm{L}^{\mathrm{OH}}$ method (b) 
considered in the calculation. The emission mechanism of different monoterpenes varies greatly in which some of the monoterpenes are reported to be positively correlated with temperature (Guenther et al. 2012). The harvesting of leaf biomass was calculated via biological parameters such as forest vegetation accumulation and trunk density. It should be noted that the manual measurement errors would also affect the accuracy of the calculation. Furthermore, the meteorological data used in this study were retrieved from the MODIS satellite published on the NASA website. The acquisition, processing, analysis and conversion of satellite data would further introduce various types and degrees of uncertainty. For example, the positioning error of the ground station, the positioning error of the satellite and the tropospheric time delay will cause the accuracy and stability of the satellite calibration and the delay error in time transmission. In addition, in the inversion process of meteorological satellite remote sensing, atmospheric state deviation, model error, model parameter error, etc., will also affect the inversion accuracy. In detail, there will be a systematic deviation between the reference temperature profile and the actual atmospheric profile during the seasonal transition, and solar radiation will cause large diurnal changes in the temperature of the troposphere bottom, which will cause inversion errors, and the errors caused are more complicated. Therefore, the estimated BVOCs emission using the satellite detection data may be higher or lower than the actual observed BVOCs emission. By comparing multiple sets of monthly measured data and satellite data, the difference between them is less than $5 \%$. Overall, it is suggested that future work should be emphasized on the reduction and prevention of those uncertainties to obtain more accurate data.

\section{Conclusions}

The total annual emission of BVOCs released from dominant forest species in the Jing-Jin-Ji area was estimated to be $70.8 \mathrm{Gg} \mathrm{C} \cdot \mathrm{year}^{-1}$. Isoprene, monoterpenes, and other VOCs contributed $40.5 \%, 36.0 \%$, and $23.4 \%$, respectively. As for monthly and seasonal variations, the emission of BVOCs was peaked in summer (June, July, and August) and bottomed out in winter (December, January, and February). This explains the summer represents the season with the most severe ozone pollution. In terms of spatial distribution, high BVOCs emission was mainly distributed in the Taihang Mountains and the Yanshan Mountains. Chengde contributed the most followed by Beijing, inferring that these two cities should have more attention to mitigate BVOCs emission to atmospheric ozone and particulate pollution. In terms of forest species, Platycladus orientalis, Quercus variabilis, Populus tomentosa, Pinus tabulaeformis and Robinia pseudoacacia were the primary contributors of BVOCs emission and atmospheric reactivity. In conclusion, it was recommended that the use of these forest species for greening configuration should be avoided since they negatively impact the atmosphere due to high emission or reactivity of BVOCs.

\section{Abbreviations}

BVOCs: Biogenic volatile organic compounds; AVOCs: Anthropogenic volatile organic compounds; G93: Guenther model developed in 1993;

NMVOCs: Non-methane volatile organic compounds; PANs: Peroxyacetyl nitrate; SOA: Secondary organic aerosols; PM: Particulate matter;

OH: Hydroxyl radical; PFT: Plant functional types; PAR: Photosynthetically active radiation; MIR: Maximum incremental reactivity; $\mathrm{L}^{\mathrm{OH}}: \mathrm{OH}$ reaction rate; OFP: Ozone formation potential; OVOCs: Other VOCs; TVOCs: Total VOCs; NIST: National Institute of Standards and Technology; PAMS: Photochemical Assessment Monitoring Stations

\section{Supplementary Information}

The online version contains supplementary material available at https://doi. org/10.1186/s40663-021-00322-y.

Additional file 1: Table A1. The parameters of dominant forest species in the Jing-Jin-Ji area. Table A2. The annual emissions of BVOCs from dominant forest species in the Jing-Jin-Ji area $\left(10^{6} \mathrm{~g} \mathrm{C} \cdot\right.$ year $\left.^{-1}\right)$. Table A3. The monthly emissions of BVOCs from dominant forest species in the Jing-Jin-Ji area $\left(10^{6} \mathrm{~g} \mathrm{C).} \mathrm{Table} \mathrm{A4.} \mathrm{The} \mathrm{BVOCs} \mathrm{emission} \mathrm{of} 13\right.$ cities

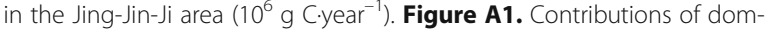
inant forest species to the components of BVOCs in the Jing-Jin-Ji area. Figure A2. The contribution of BVOCs emitted from the dominant forest species in each city in the Jing-Jin-Ji area.

\section{Acknowledgements}

Not applicable.

\section{Authors' contributions}

Xiaoxiu Lun, Qiang Wang and Ying Lin conceived the study; Ying Lin participated in study design, field measurements, data processing and writing the manuscript; Xiaoxi Jing and Chong Fan took part in the field measurements; Wei Tang and Zhongzhi Zhang took part in the procedure of data processing. All authors contributed critically to successive drafts and gave final approval for publication.

\section{Funding}

This work was supported by the grants from National Natural Science Foundation of China (No.42077454), National Research Program for Key Issues in Air Pollution Control (DQGG202126), National Natural Science Foundation of China (No. 41605077).

Availability of data and materials

The datasets used and/or analysed during the current study are available from the corresponding author on reasonable requests.

\section{Declarations}

Ethics approval and consent to participate Not applicable.

\section{Consent for publication}

Not applicable.

\section{Competing interests}

The authors declare that they have no competing interests.

\section{Author details}

${ }^{1}$ College of Environmental Science and Engineering, Beijing Forestry University, 100083 Beijing, China. ${ }^{2}$ Institute of Atmospheric Environment, Chinese Research Academy of Environmental Sciences, 100012 Beijing, China. 
Received: 22 October 2020 Accepted: 3 June 2021 Published online: 01 August 2021

\section{References}

Aksoyoglu S, Keller J, Barmpadimos I, Oderbolz D, Lanz VA, Prévôt ASH, Baltensperger U (2011) Aerosol modelling in Europe with a focus on Switzerland during summer and winter episodes. Atmos Chem Phys 11(14): 7355-7373. https://doi.org/10.5194/acp-11-7355-2011

Atkinson R, Arey J (2003) Atmospheric degradation of volatile organic compounds. Chem Rev 103(12):4605-4638. https://doi.org/10.1021/cr0206420

Carlo P, Brune WH, Martinez M, Harder H, Lesher R, Ren X, Thornberry T, Carroll MA, Young V, Shepson PB, Riemer D, Apel E, Campbell C (2004) Missing OH reactivity in a forest: evidence for unknown reactive biogenic VOCs. Science 304:722-725. https://doi.org/10.1126/science.1094392

Carlton AG, Baker KR (2011) Photochemical modeling of the Ozark isoprene volcano: MEGAN, BEIS, and their impacts on air quality predictions. Environ Sci Technol 45(10):4438-4445. https://doi.org/10.1021/es200050x

Carter WPL (1991) Development of ozone reactivity scales for volatile organic compounds. J Air Waste Manage 44:881-899. https://doi.org/10.1080/10731 61X.1994.10467290

Carter W (2008) Reactivity estimates for selected consumer product compounds Center for environmental research and technology, College of engineering, University of California

Chen P, Quan J, Zhang Q, Tie X, Gao Y, Li X, Huang M (2013) Measurements of vertical and horizontal distributions of ozone over Beijing from 2007 to 2010. Atmos Environ 74:37-44. https://doi.org/10.1016/j.atmosenv.2013.03.026

Chen WH, Guenther AB, Wang XM, Chen YH, Gu DS, Chang M, Zhou SZ, Wu LL, Zhang YQ (2018) Regional to global biogenic isoprene emission responses to changes in vegetation from 2000 to 2015. J Geophys Res-Atmos 123(7): 3757-3771. https://doi.org/10.1002/2017JD027934

Claeys M, Wang W, Ion AC, Kourtchev I, Gelencser A, Maenhaut W (2004) Formation of secondary organic aerosols from isoprene and its gas-phase oxidation products through reaction with hydrogen peroxide. Atmos Environ 38(25):4093-4098. https://doi.org/10.1016/j.atmosenv.2004. 06.001

Fehsenfeld F, Calvert J, Fall R, Goldan P, Guenther AB, Hewitt CN, Lamb B, Liu S, Trainer M, Westberg H, Zimmerman P (1992) Emissions of volatile organic compounds from vegetation and the implications for atmospheric chemistry Global Biogeochem Cy 6(4):389-430. https://doi.org/10.1029/92GB02125

Filella I, Primante C, Llusià J, Martín González AM, Seco R, Farré-Armengol G, Rodrigo A, Bosch J, Peñuelas J (2013) Floral advertisement scent in a changing plant pollinators market. Sci Rep 3(1):3434. https://doi.org/10.1038/ srep03434

Geng F, Tie X, Guenther A, Li G, Cao J, Harley P (2011) Effect of isoprene emissions from major forests on ozone formation in the city of Shanghai, China. Atmos Chem Phys 11:10449-10459. https://doi.org/10.5194/acp-11-1 0449-2011

Ghirardo A, Xie J, Zheng X, Wang Y, Grote R, Block K, Wildt J, Mentel T, KiendlerScharr A, Hallquist M, Butterbach-Bahl K, Schnitzler J-P (2016) Urban stressinduced biogenic VOC emissions and SOA-forming potentials in Beijing. Atmos Chem Phys 16(5):2901-2920. https://doi.org/10.5194/acp-16-2901-201

Goldan PD, Kuste WC, Williams E, Murphy PC, Fehsenfeld FC, Meagher J (2004) Nonmethane hydrocarbon and oxy hydrocarbon measurements during the 2002 New England air quality study. J Geophys Res-Atmos 109:D21309. https://doi.org/10.1029/2003JD004455

Guenther AB, Zimmerman PR, Harley PC, Monson RK, Fall R (1993) Isoprene and monoterpene emission rate variability: model evaluations and sensitivity analyses. J Geophys Res-Atmos 98(D7):12609-12617. https://doi.org/10.1029/ 93JD00527

Guenther A, Hewitt CN, Erickson D, Fall R, Geron C, Graedel T, Harley P, Klinger L, Lerdau M, Mckay WA, Pierce T, Scholes B, Steinbrecher R, Tallamraju R, Taylor J, Zimmerman P (1995) A global model of natural volatile organic compound emissions. J Geophys Res-Atmos 100(D5):8873-8892. https://doi.org/10.1029/ 94JD02950

Guenther AB, Jiang X, Heald CL, Sakulyanontvittaya T, Duhl T, Emmons LK, Wang $X$ (2012) The model of emissions of gases and aerosols from nature version 2.1 (MEGAN2.1): an extended and updated framework for modeling biogenic emissions. Geosci Model Dev 5:1471-1492. https://doi.org/10.5194/gmd-5-14 $71-2012$
Han X, Zhang M, Tao J, Wang L, Gao J, Wang S, Chai F (2013) Modeling aerosol impacts on atmospheric visibility in Beijing with RAMS-CMAQ. Atmos Environ 72:177-191. https://doi.org/10.1016/j.atmosenv.2013.02.030

Hogrefe C, Isukapalli S, Tang X, Georgopoulos PG, He S, Zalewsky EE, Hao W, Ku $J-Y$, Key T, Sistla G (2011) Impact of biogenic emission uncertainties on the simulated response of ozone and fine particulate matter to anthropogenic emission reductions. J Air Waste Manage 61(1):92-108. https://doi.org/10.31 55/1047-3289.61.1.92

Hsu CY, Ching HC, Chen MJ, Chuang CY, Tsen CM, Fang GC, Tsai Yl, Chen NT, Lin TY, Lin SL, Chen YC (2017) Ambient PM2.5. Sci Total Environ 590:204-214. https://doi.org/10.1016/j.scitotenv.2017.02.212

Jing X, Lun X, Fan C, Ma W (2020) Emission patterns of biogenic volatile organic compounds from dominant forest species in Beijing, China. J Environ Sci 95: 73-81. https://doi.org/10.1016/j.jes.2020.03.049

Klinger LF, Li QJ, Guenther AB, Greenberg JP, Baker B, Bai JH (2002) Assessment of volatile organic compound emissions form ecosystems of China. J Geophys Res-Atmos 107(D21):4603. https://doi.org/10.1029/2001JD001076

Kulmala M, Nieminen T, Chellapermal R, Makkonen R, Bäck J, Kerminen V-M (2013) Climate feedbacks linking the increasing atmospheric $\mathrm{CO}_{2}$ concentration, BVOC emissions, aerosols and cloudsin in forest ecosystems. In: Niinemets Ü, Monson R (eds) Biology, Controls and Models of Tree Volatile Organic Compound Emissions, vol 5. Springer, Dordrecht, pp 489508. https://doi.org/10.1007/978-94-007-6606-8_17

Laothawornkitkul J, Taylor JE, Paul ND, Hewitt CN (2009) Biogenic volatile organic compounds in the earth system. New Phytol 183(1):27-51. https://doi.org/1 0.1111/j.1469-8137.2009.02859.x

Li Z, Gu X, Wang L, Li D, Xie Y, Li K, Dubovik O, Schuster G, Goloub P, Zhang Y, Li L, Ma Y, Xu H (2013) Aerosol physical and chemical properties retrieved from ground-based remote sensing measurements during heavy haze days in Beijing Winter. Atmos Chem Phys 13(20):10171-10183. https://doi.org/10.51 94/acp-13-10171-2013

Li M, Ren X, Yu Y, Zhou L (2016) Temporal and spatial distribution of PM 25 pollution in Chinese cities. China Environ Sci 36(3):641-650 ((in Chinese))

Li J, Li LY, Wu RR, Li YQ, Bo Y, Xie SD (2016) Inventory of highly resolved temporal and spatial volatile organic compounds emission in China. Air Pollution 207(8):79-86. https://doi.org/10.2495/AIR160081

Loreto F, Bagnoli F, Fineschi S (2009) One species, many terpenes: matching chemical and biological diversity. Trends Plant Sci 14(8):416-420. https://doi. org/10.1016/j.tplants.2009.06.003

Loreto F, Schnitzler J-P (2010) Abiotic stresses and induced BVOCs. Trends Plant Sci 15(3):154-166. https://doi.org/10.1016/j.tplants.2009.12.006

Meng X, Gong Z, Ye C, Wang S, Sun H, Zhang X (2017) Characteristics of ozone concentration variation in 74 cities from 2013 to 2016. Environmental Monitoring in China 33(05):101-108. https://doi.org/10.19316/j.issn.10026002.2017.05.15 ((in Chinese))

Monson RK, Jones RT, Rosenstiel TN, Schnitzler J-P (2013) Why only some plants emit isoprene. Plant Cell Environ 36(3):503-516. https://doi.org/10.1111/ pce. 12015

Ortega J, Helmig D, Daly RW, Tanner DM, Guenther AB, Herrick JD (2008) Approaches for quantifying reactive and low-volatility biogenic organic compound emissions by vegetation enclosure techniques-part B: applications. Chemosphere 72(3):365-380. https://doi.org/10.1016/j. chemosphere.2008.02.054

Owen SM, Harley P, Guenther A, Hewitt CN (2002) Light dependency of VOC emissions from selected Mediterranean plant species. Atmos Environ 36(19): 3147-3159. https://doi.org/10.1016/S1352-2310(02)00235-2

Pierre S, Alessandro A, Alessandra DM, Elena P (2017) Projected global tropospheric ozone impacts on vegetation under different emission and climate scenarios. Atmos Chem Phys. https://doi.org/10.5194/acp-2017-74

Ran L, Zhao CS, Xu WY, Lu XQ, Han M, Lin WL, Yan P, Xu XB, Deng ZZ, Ma N, Lin PF, Yu J, Liang WD, Chen LL (2011) VOC reactivity and its effect on ozone production during the HaChi summer campaign. Atmos Chem Phys 11(10): 4657-4667. https://doi.org/10.5194/acp-11-4657-2011

Sartelet KN, Couvidat F, Seigneur C, Roustan Y (2012) Impact of biogenic emissions on air quality over Europe and North America. Atmos Environ 53: 131-141. https://doi.org/10.1016/j.atmosenv.2011.10.046

Song Y, Zhang Y, Wang Q, An J (2012) Estimation of biogenic VOCs emissions in Eastern China based on remote sensing data. Acta Sci Circumst 32(9):22162227 ((in Chinese))

Steinbrecher R, Smiatek G, Köble R, Seufert G, Theloke J, Hauff K Ciccioli P, Vautard R, Curci G (2009) Intra- and inter-annual variability of VOC emissions 
from natural and semi-natural vegetation in Europe and neighbouring countries. Atmos Environ 43(7):1380-1391. https://doi.org/10.1016/j.a tmosenv.2008.09.072

Tang G, Li X, Wang Y, Xin J, Ren X (2009) Surface ozone trend details and interpretations in Beijing, 2001-2006. Atmos Chem Phys 9(22):8813-8823. https://doi.org/10.5194/acp-9-8813-2009

Wang X, Feng Z, Ouyang Z (2001) The impact of human disturbance on vegetative carbon storage in forest ecosystems in China. Forest Ecol Manag 148(1-3):117-123. https://doi.org/10.1016/S0378-1 127(00)00482-5

Wang L, Xu J, Yang J, Zhao X, Wei W, Cheng D, Pan X, Su J (2012) Understanding haze pollution over the southern Hebei area of China using the CMAQ model. Atmos Environ 56:69-79. https://doi.org/10.1016/j.atmosenv.2012.04. 013

Wang T, Xue L, Brimblecombe P, Lam YF, Li L, Zhang L (2017) Ozone pollution in China: a review of concentrations, meteorological influences, chemical precursors, and effects. Sci Total Environ 575:1582-1596. https://doi.org/10.1 016/j.scitotenv.2016.10.081

Xia C, Xiao L (2019) Estimation of biogenic volatile organic compounds emissions in Jing-Jin-Ji. Acta Sci Circumst 39(8):2680-2689 ((in Chinese))

Xie X, Shao M, Liu Y, Lu S, Chang C-C, Chen Z-M (2008) Estimate of initial isoprene contribution to ozone formation potential in Beijing, China. Atmos Environ 42(24):6000-6010. https://doi.org/10.1016/j.atmosenv.2008.03.035

Zhai S, An X, Zhao T, Sun Z, Wang W, Hou Q, Guo Z, Wang C (2016) Detect of critical $\mathrm{PM}_{2.5}$ emission sources and their contributions to a heavy haze episode in Beijing, China by using an adjoint mode. Atmos Chem Phys. https://doi.org/10.5194/acp-2016-911

Zhang Q, Li H, He M, Lv L, Yang J (2018) Estimation of volatile organic compounds emission from frequently-used greening tree species in Tianjin City. Res Environ Sci 31(2):245-253 ((in Chinese))

Zhao PS, Dong F, He D, Zhao XJ, Zhang XL, Zhang WZ, Yao Q, Liu HY (2013) Characteristics of concentrations and chemical compositions for $\mathrm{PM}_{2.5}$ in the region of Beijing, Tianjin, and Hebei, China. Atmos Chem Phys 13(9):46314644. https://doi.org/10.5194/acp-13-4631-2013

Zhao H, Zheng Y, Zhang Y, Wang Z (2020) Spatiotemporal distribution and population exposure of air pollution in Beijing-Tianjin-Hebei region. Acta Sci Circumst 40(1):1-12 ((in Chinese))

\section{Submit your manuscript to a SpringerOpen ${ }^{\circ}$ journal and benefit from:}

- Convenient online submission

- Rigorous peer review

- Open access: articles freely available online

High visibility within the field

- Retaining the copyright to your article

Submit your next manuscript at $\boldsymbol{\nabla}$ springeropen.com 